University of Nebraska - Lincoln

DigitalCommons@University of Nebraska - Lincoln

\title{
Post-biological control invasion trajectory for Melaleuca quinquenervia in a seasonally inundated wetland
}

\author{
Philip W. Tipping \\ USDA-ARS Invasive Plant Research Laboratory, Philip.tipping@ars.usda.gov \\ Melissa R. Martin \\ US Fish and Wildlife Service \\ Ryan Pierce \\ Alan Plummer Associates \\ Ted D. Center \\ USDA-ARS Invasive Plant Research Laboratory \\ Paul R. Pratt \\ USDA-ARS Invasive Plant Research Laboratory \\ See next page for additional authors
}

Follow this and additional works at: https://digitalcommons.unl.edu/usdaarsfacpub

Part of the Agricultural Science Commons

Tipping, Philip W.; Martin, Melissa R.; Pierce, Ryan; Center, Ted D.; Pratt, Paul R.; and Rayamajhi, Min B., "Post-biological control invasion trajectory for Melaleuca quinquenervia in a seasonally inundated wetland" (2012). Publications from USDA-ARS / UNL Faculty. 879.

https://digitalcommons.unl.edu/usdaarsfacpub/879

This Article is brought to you for free and open access by the U.S. Department of Agriculture: Agricultural Research Service, Lincoln, Nebraska at DigitalCommons@University of Nebraska - Lincoln. It has been accepted for inclusion in Publications from USDA-ARS / UNL Faculty by an authorized administrator of DigitalCommons@University of Nebraska - Lincoln. 


\section{Authors}

Philip W. Tipping, Melissa R. Martin, Ryan Pierce, Ted D. Center, Paul R. Pratt, and Min B. Rayamajhi 


\title{
Post-biological control invasion trajectory for Melaleuca quinquenervia in a seasonally inundated wetland
}

\author{
Philip W. Tipping a,*, Melissa R. Martin ${ }^{\mathrm{b}}$, Ryan Pierce ${ }^{\mathrm{c}}$, Ted D. Center ${ }^{\mathrm{a}}$, Paul R. Pratt ${ }^{\mathrm{a}}$, Min B. Rayamajhi ${ }^{\mathrm{a}}$ \\ ${ }^{a}$ USDA-ARS Invasive Plant Research Laboratory, Ft. Lauderdale, FL 33314, USA \\ ${ }^{\mathrm{b}}$ US Fish and Wildlife Service, A.R.M. Loxahatchee National Wildlife Refuge Boynton Beach, FL 33473-4797, USA \\ c Alan Plummer Associates, Inc., Dallas, TX 75247-4066, USA
}

\section{H I G H L I G H T S}

- We examined the recruitment and mortality of Melaleuca quinquenervia in the Everglades.

- Post-biocontrol populations were $99 \%$ smaller than pre-biocontrol populations.

- Biocontrol agents did not increase mortality of weed seedlings.

- Weed invasion trajectory likely changed by depleted aerial seed banks.
G R A P H I C A L A B S T R A C T

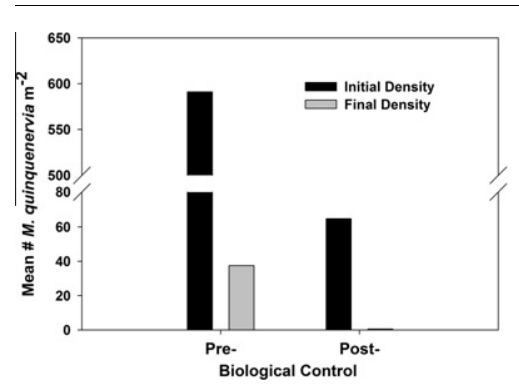

\begin{abstract}
A B S T R A C T
The recruitment and mortality of Melaleuca quinquenervia seedlings were evaluated over a 3-year period in a seasonally inundated wetland in the western Everglades region. The mean $( \pm$ SE) density of seedlings/ saplings $\mathrm{m}^{-1}$ declined from $64.8( \pm 4.5)$ to $0.5( \pm 0.2)$ over the 3 years, a population reduction of $99.2 \%$. Four distinct water regimes characterized this site: dry, dry to wet transition, flooded, and wet to dry transition. Seedling recruitment was highest in the dry to wet transition and lowest in the flooded water regime, while mortality was highest under flooded and dry water regimes. The mean estimate of population growth $(\lambda)$ across water regimes was $0.64 \pm 0.05$ indicating negative population growth. Elimination of introduced insect herbivores using insecticides did not reduce mortality of recruited M. quinquenervia seedlings/saplings indicating that direct herbivory was not responsible for the decline in seedling density. On the other hand, a mean of only $0.2( \pm 0.03)$ viable seeds $\mathrm{m}^{-2} \mathrm{~d}^{-1}$ fell into the plots, an amount considerably lower than in previous studies. We submit that change in the invasion trajectory M. quinquenervia was most likely caused by reduced seed inputs from aerial seed banks depleted by insect herbivory rather than direct herbivory on seedlings. This may indicate a fundamental alteration of $M$. quinquenervia population dynamics ultimately resulting in a less invasive and, therefore, less ecologically damaging species.
\end{abstract}

Published by Elsevier Inc.

\section{Introduction}

Exotic plants that successfully invade new ranges often possess a high reproductive capacity which enables them to outcompete

* Corresponding author. Present address: USDA-ARS Invasive Research Laboratory, 3225 College Ave., Davie, FL 33314, USA. Fax: +1 9544769169.

E-mail address: Philip.tipping@ars.usda.gov (P.W. Tipping). native species by swamping available seed microsites with propagules (Reichard and Hamilton, 1997; Mason et al., 2008; Martin and Canham, 2010). A high degree of propagule pressure is considered vital for successful invasion and establishment into new habitats (Rouget and Richardson, 2003). However, the relationship between seed inputs and recruited seedlings are often non-linear (Poulsen et al., 2007) as a result of microsite limitations (Clark et al., 2007) and density-dependent factors such as intraspecific 
competition (Conduit et al., 1994). In addition to higher fecundity, exotic invasive species often exhibit early reproduction, effective seed dispersal, fast population growth, vegetative reproduction, release from natural enemies, or dependence on non-specific mutualisms (Rejmánek and Richardson, 1996; Pysek and Richardson, 2007).

Water regimes are often the most important factor in determining the spatial and temporal heterogeneity of wetland plant communities (van der Valk, 2005; Watt et al., 2007; Raulings et al., 2010). Hydrology can regularly limit seed microsites which, in turn, influence germination, seedling recruitment, and seedling mortality (Froend and Van der Moezel, 1994; Keddy and Ellis, 1985). Casanova and Brock (2000) found the duration of flooding to be more important than depth in determining plant communities, and that species were grouped according to their response to fluctuations in the water regime. Water regimes can also serve as environmental triggers for seed release from species with aerial seed banks (Hamilton-Brown et al., 2009). Triggers may be location specific; rainforest trees growing in perennially wet sites release more seed during the wet season, while trees growing in dry sites release more seed in the dry season (Russell-Smith and Setterfield, 2006).

One such non-native invasive species that invades wetlands and produced copious amounts of seeds from an aerial seed bank is Melaleuca quinquenervia (Cav.) S.T. Blake. The origin, natural history, and management of this tree in Florida were summarized by Serbesoff-King (2003). The intentional introduction of Oxyops vitiosa Pascoe (Coleoptera: Curculionidae) in 1997 as part of a classical biological control project provided the first significant herbivore pressure on M. quinquenervia (Center et al., 2000). As a result of overcompensation to herbivory from this insect, reproduction in individual trees was reduced by $80-100 \%$ (Pratt et al., 2005; Tipping et al., 2008, 2009). In concert with reducing aerial seed banks, $O$. vitiosa also directly damages older saplings resulting in reduced population densities (Tipping et al., 2009). A second insect, Boreioglycaspis melaleucae Moore (Hemiptera: Psyllidae) was released in 2002 and is now widely distributed (Center et al., 2007). The impact of this species on reproductive M. quinquenervia trees is unclear but appears to be relatively minor compared to $O$. vitiosa (Tipping et al., 2008).

The objective of this study was to quantify the post-biological control invasion trajectory of M. quinquenervia in a seasonally inundated wetland characteristic of the western Everglades area. Specifically, this included determining if reproductive M. quinquenervia can still serve as potential invasion source despite herbivory by $O$. vitiosa for more than a decade. A secondary objective was to measure the impact of herbivory on newly recruited seedlings. Two hypotheses were proposed: (1) post-biological control densities of recruited $M$. quinquenervia populations would be equivalent to those recruited pre-biological control, and (2) direct herbivory would have no effect on survival of recruited seedlings of M. quinquenervia.

\section{Materials and methods}

\subsection{The study area}

Experimental plots were located in a 19-ha section of the Belle Meade tract (ca. 6700 ha) within the Picayune Strand State Forest $(29,000$ ha) located near Naples, Florida. This area consists of nearly level, poorly drained, low fertility soils which are loamy, siliceous, hyperthermic Arenic Glassoqualfs. The soil series is Pineda-Boca-Hallandale which is characterized by moderately to poorly drained sands over-lying limestone bedrock at a depth of approximately $1.4 \mathrm{~m}$ (USDA, 1998). The top $5 \mathrm{~cm}$ of soil in the plots contained $4.1 \%$ organic matter, $18.5 \mathrm{mg} \mathrm{g}^{-1}$ carbon, $0.8 \mathrm{mg} \mathrm{g}^{-1}$ nitrogen, and $18.1 \mathrm{mg} \mathrm{g}^{-1}$ phosphorus with a pH of 5.3 (Martin et al., 2009). The water table fluctuates annually between greater than $15 \mathrm{~cm}$ below the soil surface to approximately $25 \mathrm{~cm}$ above. The area has a distinct wet season from approximately July to December and a dry season from January to June. Average annual rainfall in this region is approximately $1.36 \mathrm{~m}$ (SERC, 2007).

The Belle Meade tract is comprised of cypress strands, wet prairies, and pine flatwood communities with important native species like slash pine (Pinus elliotii var. densa Little and Dorman), pond cypress (Taxodium ascendens Brongn.), cabbage palm (Sabal palmetto [Walt.] Lodd. ex. J.S. Schult. and J.H. Schult.), saw palmetto (Serenoa repens [Bartr.] Small), waxmyrtle (Morella cerifera (L.) Small), and sawgrass (Cladium jamaicensis Crantz). M. quinquenervia has invaded this area over the years and replaced many of the native communities with large monospecific stands of various-aged trees, a process expedited by several successive canopy fires. A large fire in 1998 resulted in a major recruitment event where recruited seedling densities exceeded $591 \mathrm{~m}^{-2}$ (Center, unpublished data) and formed the pre-herbivory cohort of plants included in this study.

Four distinct water regimes were characterized at this site, namely (1) dry: no standing water in any plots for two consecutive sampling periods, (2) dry to wet transition: sampling periods between dry stages and flooded stages with some standing water in some plots and followed eventually by a sampling period with complete soil submergence, (3) flooded: complete submergence of soil in all plots, and (4) wet to dry transition: sampling periods between flooded stage and dry stage with some standing water in some plots followed eventually by a sampling period with no standing water. Although the boundaries of these periods were somewhat arbitrary they realistically describe field conditions as well as the direction of hydrologic change. In most cases the sequence of water regimes were unidirectional, normally transitioning from dry to flooded, and then back to dry (Fig. 1).

\subsection{Sampling design}

Ten reproductive $M$. quinquenervia trees (mean height $\pm \mathrm{SE}$ : $12.5 \pm 1.2 \mathrm{~m}$ ) located at least $100 \mathrm{~m}$ from other reproductive trees were identified and four $1 \mathrm{~m}^{2}$ quadrats were established in cardinal directions within their seed shadows (within $2 \mathrm{~m}$ from the trunk). Existing $M$. quinquenervia seedlings and saplings within each of the quadrats were counted (mean \pm SE: $64.8 \pm 4.5$ ) and then removed by hand along with the leaf litter to facilitate seed germination and seedling recruitment (Fowler, 1986; Hamrick and Lee,

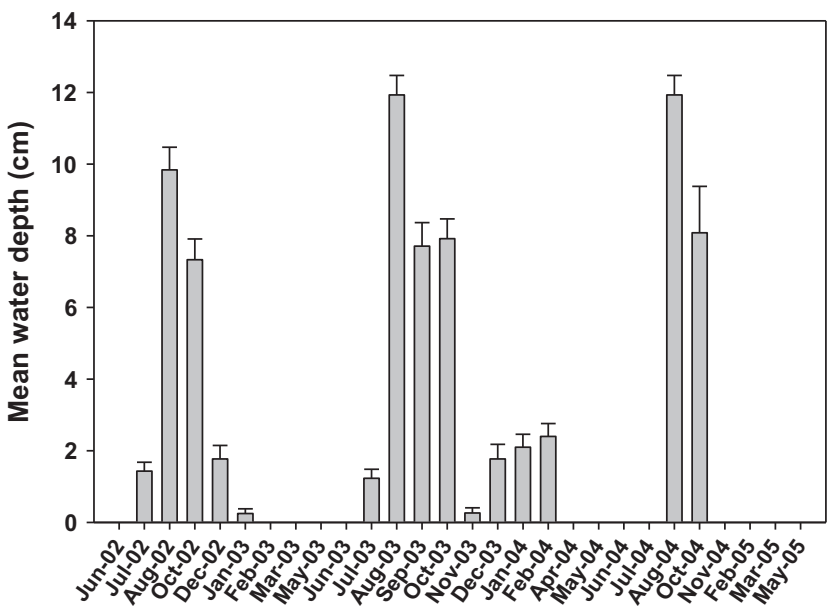

Fig. 1. Mean $( \pm S E)$ water depths at the Belle Meade experimental plots. 
1987; Borchet et al., 1989). Four seed traps were deployed on the outer edge of each quadrat furthest from the test tree. These consisted of plastic plant pots attached, approximately $123 \mathrm{~cm}$ above the soil surface, to metal poles. Each had a $531 \mathrm{~cm}^{2}$ opening and a nylon liner to retain seeds. Plots were sampled at 6-7 w intervals starting in July 2002 through May 2005 and examined for the presence of $M$. quinquenervia seedlings which were counted and marked with wire flags. At each subsequent sample date, the existing seedling/saplings were tallied and those that could not be found were considered to have died.

Water depth was measured in the center of each of the four quadrats and an average depth was calculated for each tree. Soil was collected in the top $5 \mathrm{~cm}$ adjacent to each quadrat and bulked to determine soil saturation using gravimetric methods. During the flooded conditions, two observers visually estimated to the nearest $10 \%$ the percentage of the water surface in the quadrats that was covered by algae. Seeds were collected, bulked per test tree, returned to the lab and counted. They were then spread on a bed of sand in individual pots which were watered from the bottom, and placed in a greenhouse under ambient environmental conditions until germination occurred. Seedlings were counted, removed, and the surface soil gently stirred to rearrange soil microtopography in order to encourage additional germination. Any additional seedlings were treated as above and pots were stirred three times before the samples were discarded. It was assumed that post-dispersal seed losses from invertebrates were minimal to non-existent because no organisms, including ants, were ever observed harvesting $M$. quinquenervia seeds.

Records were made of the combined number of seedlings and saplings that were infested with adults and larvae of $O$. vitiosa or with discrete groups of adults and nymphs of $B$. melaleucae. Third through fifth instars of $B$. melaleucae secrete a white, waxy flocculence which covers their feeding aggregations and makes them easy to detect (Purcell et al., 1997). Starting on 27 January 2004 the insecticide acephate (OS-dimethyl acetylphosphor-amidothiote) was applied at a concentration of $0.367 \%$ ai $(\mathrm{v} / \mathrm{v})$ to all plant foliage until runoff in two randomly chosen quadrats at every sampling date (Tipping and Center, 2002). Plants in the remaining two quadrats were sprayed with water. Plots were sampled 26 times over a 3 year period; ten samples were taken during dry water regimes, three during transition from dry to wet water regimes, six during flooded water regimes, and seven during transition from wet to dry water regimes. Records of mean daily temperatures and \%RH were obtained from a nearby weather station (Fig. 2).

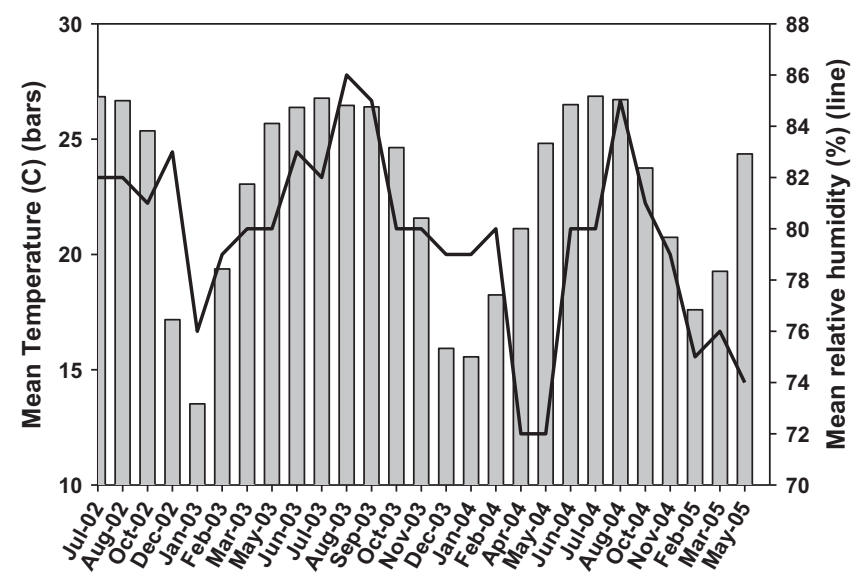

Fig. 2. Mean daily temperatures and relative humidities.

\subsection{Statistical analysis}

Biotic and abiotic variables like percent recruitment, mortality, the number of new seedlings per day, the number of viable seeds raining into plots per day, and water depth were compared among water regimes using ANOVA for repeated measures (SAS, 1999). Sphericity (equal covariances among groups) was evaluated using Mauchley's test and, if the sphericity assumption was violated, the univariate test degrees of freedom were adjusted using the Huynh-Fedt correction factor (SAS, 1999). Mean population growth $(\lambda)$ between sample periods was estimated using the equation:

$\lambda=N_{t} / N_{t-1}$

where $N_{t}$ is the number of seedlings/saplings at sample time $t$. We also compared the recruitment function $(R)$, which is the ratio of the seed inputs to subsequent seedling densities, across water regimes using the formula:

$R=$ seedlings $_{i} /$ seeds $_{i}$

where seedlings $s_{i}$ are the number of seedlings recruited at sample time $i$ and seeds $s_{i}$ are the number of viable seeds raining into plots at sample time $i$. We estimated that seed viability was $9 \%$ based on studies by Rayachhetry et al. (1998).

\section{Results}

The reinvasion trajectory of the new $M$. quinquenervia population consisted of both lower initial and final densities than the previous population. Specifically, the density of the recruited melaleuca population was $99.2 \%$ lower than the population it replaced 3 years previously $\left(64.8 \pm 4.5\right.$ and $0.5 \pm 0.2 \mathrm{~m}^{-2}$ for 1998 and 2003, respectively). Although $\lambda$ varied by water regime, it was never above 1.0 and, with an overall mean $\lambda$ of 0.64 , population growth rate was negative (Table 1 ). The growth rate was highest during the dry water regime, lowest during the flooded water regime, and intermediate for the transitions (Table 1 ).

Despite any initial disturbance that may have occurred while establishing the plots, mean seedling recruitment was uniformly low from the first four sample periods $(0.04 \pm 0.01$ recruited seedlings $\mathrm{m}^{-2} \mathrm{~d}^{-1}$ ) when disturbance could have been a factor, through the remaining sample periods $(0.03 \pm 0.003$ recruited seedlings $\left.\mathrm{m}^{-2} \mathrm{~d}^{-1}\right)\left(F_{1862}=1.6 ; P=0.19\right)$. The recruitment function was highest during the dry period which may reflect the presence of more mineral soil and less litter thereby increasing germination because of better seed to soil contact. Layers of organic material that are usually deposited on the soil during flooding water regimes decompose and eventually disappear from the soil surface during the dry regime. Over the course of this study a mean $( \pm \mathrm{SE})$ of 0.2 $( \pm 0.03)$ viable seeds $\mathrm{m}^{-2} \mathrm{~d}^{-1}$ rained into the plots. Seed rain peaked during the dry-to-wet and flooded water regimes and was lowest during the dry and the wet-to-dry water regimes (Table 1). The recruitment function was highest during the dry water regime when a mean $( \pm$ SE) of $1.1( \pm 0.3) \%$ of the seeds produced seedlings, and equally lower in the other water regimes (Table 1). Recruitment was highest during transition water regimes and lowest during the flooded regimes, while mortality was highest under flooded and dry water regimes (Table 1$)$. Mean $( \pm \mathrm{SE}$ ) algal coverage in this study was $26.1 \pm 3.5 \%$ during the flooded water regime and $12.2 \pm 2.3 \%$ during the wet to dry water regime. There were no differences in recruitment $\left(F_{3,892}=0.24, P>0.86\right)$ (Fig. 3) or mortality $\left(F_{3,892}=0.46, P>0.71\right)$ (Fig. 4$)$ of seedling populations in plots sprayed with insecticides under any water regime. 
Table 1

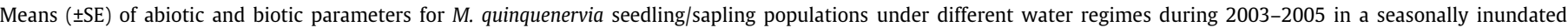
wetland.

\begin{tabular}{|c|c|c|c|c|c|c|c|}
\hline $\begin{array}{l}\text { Water } \\
\text { regimes }\end{array}$ & $\begin{array}{l}\text { Water depth } \\
(\mathrm{cm})^{A}\end{array}$ & $\begin{array}{l}\text { Soil moisture } \\
(\%)\end{array}$ & $\begin{array}{l}\text { Population growth } \\
(\lambda)\end{array}$ & $\begin{array}{l}\text { Seed rain } \\
\left(\mathrm{m}^{-2} \mathrm{~d}^{-1}\right)\end{array}$ & $\begin{array}{l}\text { Recruitment } \\
\text { function }\end{array}$ & $\begin{array}{l}\text { Population recruitment } \\
\text { (\%) }\end{array}$ & $\begin{array}{l}\text { Population mortality } \\
(\%)\end{array}$ \\
\hline Dry & $0 \pm 0 \mathrm{~d}$ & $1.1+1.5 \mathrm{c}$ & $0.8 \pm 0.1 \mathrm{a}$ & $0.1 \pm 0.03 \mathrm{~b}$ & $1.1 \pm 0.3 \mathrm{a}$ & $12.3 \pm 1.4 \mathrm{~b}$ & $18.2 \pm 1.7 \mathrm{a}$ \\
\hline Dry-Wet & $0.82 \pm 0.13 c$ & $12.7+6.4 b$ & $0.5 \pm 0.1 \mathrm{ab}$ & $0.5 \pm 0.1 \mathrm{a}$ & $0.11 \pm 0.04 b$ & $23.6 \pm 4.2 \mathrm{a}$ & $10.1 \pm 2.9 \mathrm{~b}$ \\
\hline Flooded & $14.1 \pm 0.91 \mathrm{a}$ & $36.6+2.5 a$ & $0.4 \pm 0.03 b$ & $0.4 \pm 0.1 \mathrm{a}$ & $0.01 \pm 0.01 \mathrm{~b}$ & $1.6 \pm 0.01 \mathrm{c}$ & $21.2 \pm 2.4 \mathrm{a}$ \\
\hline Wet-Dry & $2.07 \pm 0.26 b$ & $17.5+6.1 b$ & $0.7 \pm 0.05 \mathrm{ab}$ & $0.1 \pm 0.05 b$ & $0.2 \pm 0.1 \mathrm{~b}$ & $15.9 \pm 1.9 \mathrm{~b}$ & $10.7 \pm 1.7 b$ \\
\hline
\end{tabular}

A Means within columns followed by different letters are significantly different using Tukey's HSD (SAS, 1999).

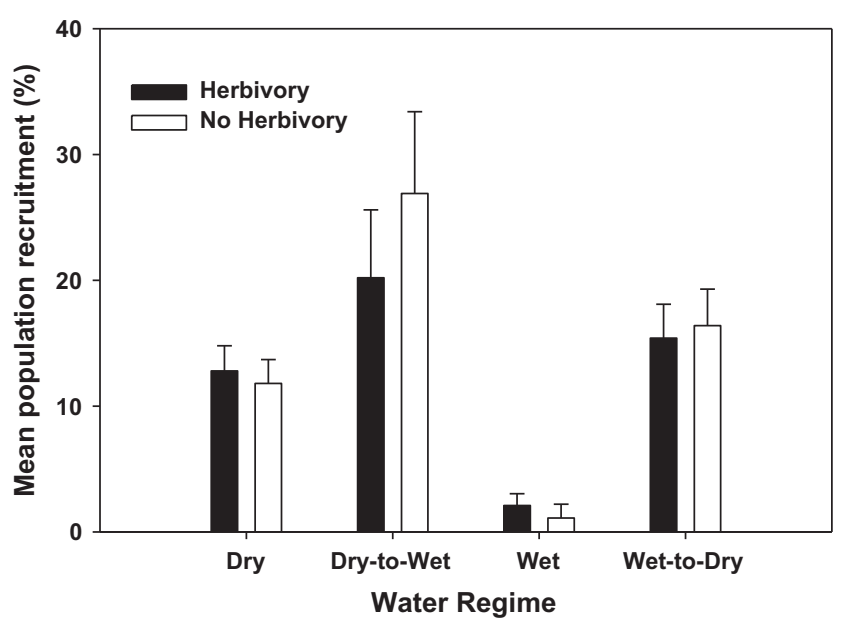

Fig. 3. Mean $( \pm \mathrm{SE})$ percent recruitment of herbivore protected and unprotected $M$. quinquenveria populations in each water regime.

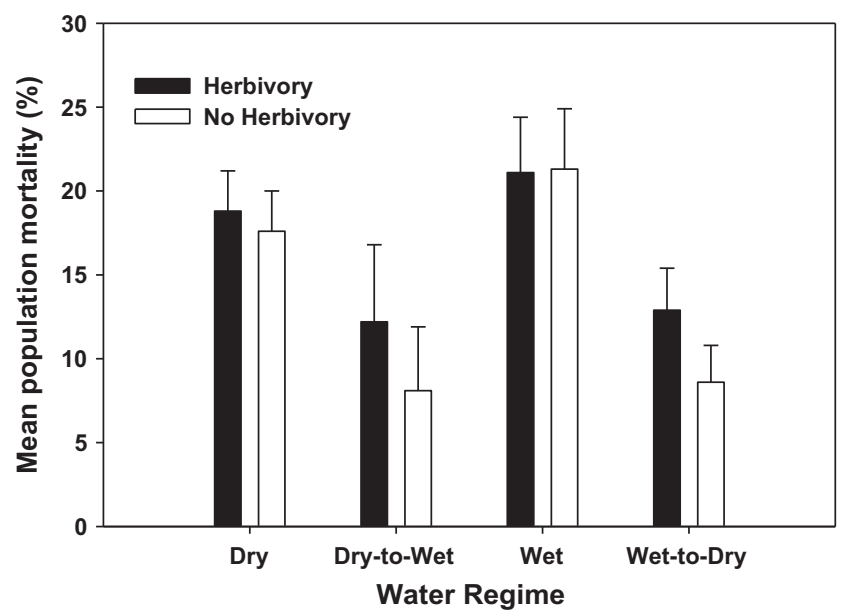

Fig. 4. Mean $( \pm S E)$ mortality of herbivore protected and unprotected M. quinquenervia populations in each water regime.

\section{Discussion}

Although the local population was recruited primarily after a fire, removing those recruits from our plots meant that any new recruitment did not depend on perturbations like fires, but rather on regular seed rain from the aerial seed bank, supplemented by local dispersal and seeds from the soil seed bank. Fires usually cause massive, synchronous releases of seeds that results in high density recruitment (Van et al., 2002). In this study, the number of seeds raining into plots was low compared to other studies, with the greatest seed rain of less than 1 viable seed $\mathrm{m}^{-2} \mathrm{~d}^{-1}$. In comparison, Woodall (1982) reported a daily seed fall of 29.1 seeds $\mathrm{m}^{-2} \mathrm{~d}^{-1}$ after correcting for viability. The difference could be a function of the methods employed; in this study seed rain was collected for 36 months directly under individual trees while Woodall (1982) collected for 6 months in a closed stand of mature trees. It could also be readily explained by regular reductions in seed production in individual trees by $O$. vitiosa herbivory which cumulatively reduced the overall aerial seed bank of pre-biological control reproductive trees. The percent change in seed rain between this experiment and Woodall (1982) is 99\%, which mirrors the reduction in seed production of individual trees reported by Tipping et al. (2008).

Although there were no significant continuous relationships with seed rain and water depth or temperature, seed rain peaked during our discrete dry-to-wet and flooded water regimes. HamiltonBrown et al. (2009) also did not find consistent relationships with seed rain along the continuum of abiotic conditions with Melaleuca ericifolia Smith. Kolb and Barsch (2010) found more Phyteuman spicatum L. (Campanulaceae) recruitment during the transition between dry and flooded conditions where soil was moist and seed rain was greatest. Salter et al. (2010) reported that recruitment of M. ericifolia was likely during drawdown, which was equivalent to wet to dry transitions in this study. In this experiment, recruitment was lowest during dry and flooded water regimes while mortality was greatest. Although not directly measured, younger seedlings in both water regimes appeared to be more vulnerable, either to drought because of less developed tap roots, or to smothering by algae if their heights did not exceed the depth of the water, an outcome also reported by Lockart et al. (1999) in pot studies. Myers (1983) reported that seedlings recruited from seeds that germinated at the close of the wet season in the field (the flooded water regime in this study) often did not survive the dry season, while those that germinated at the onset of the wet season often did not survive the extended period of flooding.

Populations of $M$. quinquenervia growing under the fluctuating water regimes of this site, without continuous and abundant seed inputs, appear to be limited with respect to population recruitment and spread. One explanation for reduced seed inputs is the reduced size of aerial seed banks in reproductive trees as a result of sustained herbivory by introduced insects. Since protecting seedlings with insecticides did not increase their survival, this suggests that seed bank depletion is primarily responsible for the changes in $M$. quinquenervia invasion trajectory that was observed. Pre-biological control populations of $M$. quinquenervia were considered less likely to suffer negative population impacts of seed predation (Anderson, 1989; Crawley, 1989). The primary reason is that if superabundant seeds fill all potential microsites many times over, then reductions of seeds will not significantly affect recruitment and eventual plant abundance. According to this scenario, invading populations of M. quinquenervia are likely to be microsite limited, especially in flooded water regimes. However, Maron and Gardner (2000) suggested that even species with long-lived seed banks and the ability to recruit episodically after disturbances would suffer significant reductions in population size across many years if their seed production was limited by herbivores. 
A question for future examination is what level of losses over what length of time is necessary to shift a formerly microsite limited species like $M$. quinquenervia to a seed limited one, a category that includes up to $50 \%$ of all plant populations (Turnbull et al., 2000). Reduced seed inputs have the potential to intensify the seed to seedling bottleneck to the point where $M$. quinquenervia can no longer as successfully invade new areas or re-invade cleared areas. With lower seed inputs from depleted aerial seed banks, the normally high seedling mortality rate may no longer be offset by increased recruitment, ultimately resulting in landscape-level population declines. A similar outcome was reported in South Africa with Sesbania punicea (Cav.) Benth. where attack by a suite of agents reduced seed production by $99.7 \%$ which eventually resulted in population level declines of mature trees (Hoffmann and Moran, 1998). In Australia, populations of Mimosa pigra L. attacked by the biological control agent Carmenta mimosa Eichlin \& Passoa (Lepidoptera: Sesiidae) produced about 96\% less seed, supported greater plant diversity within their formerly monotypic stands, and eventually experienced landscape-level declines (Paynter, 2005).

This study provided compelling evidence of the transformation of a troublesome exotic plant into a less invasive form via reduced propagule pressure, as a direct result of intentional releases of monophagous insect herbivores. As such, it reaffirms the potential of classical biological control to constrain the invasiveness of certain exotic plants and restore some degree of competitive balance to plant communities. As evidenced in this study, land managers now face less pressure to eliminate existing reproductive $M$. quinquenervia trees as soon as possible to avoid reinfestation or contain spread. Older M. quinquenervia trees, despite the continued, albeit greatly reduced presence of flowering and infructescences, can be removed as time and budgets allow.

\section{Acknowledgment}

We thank Eileen Pokorny for assisting in sample processing.

\section{References}

Anderson, A.N., 1989. How important is seed predation to recruitment in stable populations of long-lived perennials? Oecologia 81, 310-315.

Borchet, M.I., Davies, F.W., Michaelsen, J., 1989. Interaction of factors affecting seedling recruitment in blue oak (Quercus douglasi) in California. Ecology 70, 389-404.

Casanova, M.T., Brock, M.A., 2000. How do depth, duration and frequency of flooding influence the establishment of wetland plant communities? Plant Ecology 147, 237-250.

Center, T.D., Van, T.K., Rayachhetry, M.B., Buckingham, G.R., Dray, F.A., Wineriter, S.A., Purcell, M.F., Pratt, P.P., 2000. Field colonization of the melaleuca snout beetle (Oxyops vitiosa) in south Florida. Biological Control 19, 112-113.

Center, T.D., Pratt, P.D., Tipping, P.W., Rayamajhi, M.B., Van, T.K., Wineriter, S.A. Dray Jr., F.A., 2007. Initial impacts and field validation of host range for Boreioglycaspis melaleucae Moore (Hemiptera: Psyllidae), a biological control agent of the invasive tree Melaleuca quinquenervia (Cav.) Blake (Myrtales: Myrtaceae: Leptospermoidae). Biological Control 36, 569-576.

Clark, C.J., Poulsen, J.R., Levey, D.J., Osenberg, C.W., 2007. Are plant populations seed limited? A critique and meta-analysis of seed addition experiments. American Naturalist 170, 128-142.

Conduit, R., Hubbell, S.P., Foster, R.B., 1994. Density dependence in two understory tree species in a neotropical forest. Ecology 75, 671-680.

Crawley, M.J., 1989. Insect herbivores and plant population dynamics. Annual Review of Entomology 34, 531-564.

Fowler, N.L., 1986. Microsite requirements for germination and establishment of three grass species. American Midland Naturalist 115, 131-145.

Froend, R.H., Van der Moezel, P.G., 1994. The impact of prolonged flooding on the vegetation of Coomalbidgup Swamp, Western Australia. Journal of the Royal Society of Western Australia 77, 15-22.

Hamilton-Brown, S., Boon, P.I., Raulings, E., Morris, K., Robinson, R., 2009. Aerial seed storage in Melaleuca ericifolia Sm. (Swamp Paperbark): environmental triggers for seed release. Hydrobiologia 620, 121-133.
Hamrick, J.L., Lee, J.M., 1987. Effects of soil surface topography and litter cover on germination, survival and growth of musk thistle. American Journal of Botany 74, 451-457.

Hoffmann, J.H., Moran, V.C., 1998. The population dynamics of an introduced tree, Sesbania punicea, in South Africa, in response to long-term damage caused by different combinations of three species of biological control agents. Oecologia $114,343-348$

Keddy, P.A., Ellis, T.H., 1985. Seedling recruitment of 11 wetland plant species along a water level gradient: shared or distinct responses? Canadian Journal of Botany 63, 1876-1879.

Kolb, A., Barsch, K., 2010. Environmental factors and seed abundance influence seedling emergence of a perennial forest herb. Acta Oecologica. doi:10.1016/ j.actao.2010.07.003.

Lockhart, C., Austin, D.F., Aumen, N.G., 1999. Water level effects on growth of Melaleuca quinquenervia seedlings from Lake Okeechobee (Florida, USA) littoral zone. Environmental Management 23, 507-518.

Maron, J.L., Gardner, S.N., 2000. Consumer pressure, seed versus safe-site limitation, and plant population dynamics. Oecologia 124, 260-269.

Martin, M.R., Tipping, P.W., Sickman, J.O., 2009. Invasion by an exotic tree alters above and belowground ecosystem components. Biological Invasions 11, 18831894.

Martin, P.H., Canham, C.D., 2010. Dispersal and recruitment limitation in native versus exotic tree species: life-history strategies and Janzen-Connell effect. Oikos 119, 807-824.

Mason, R.A.B., Cooke, J., Moles, A.T., Leishman, M.R., 2008. Productive output of invasive versus native plants. Global Ecology and Biogeography 17, 633-640.

Myers, R.L., 1983. Site susceptibility to invasion by the exotic tree Melaleuca quinquenervia in southern Florida. Journal of Applied Ecology 20, 645-658.

Paynter, Q., 2005. Evaluating the impact of a biological control agent Carmenta mimosa on the woody wetland weed Mimosa pigra in Australia. Journal of Applied Ecology 2005, 1054-1062.

Poulsen, J.R., Osenberg, C.W., Clark, C.J., Levey, D.J., Bolker, B.M., 2007. Plants as reef fish: fitting the function form of seedling recruitment. American Naturalist 170, 167-183.

Pratt, P.D., Rayamajhi, M.B., Van, T.K., Center, T.D., Tipping, P.W., 2005. Herbivory alters resource allocation and compensation in the invasive tree Melaleuca quinquenervia. Ecological Entomology 30, 316-326.

Purcell, M.F., Balciunas, J.K., Jones, P., 1997. Biology and host-range of Boreioglycaspis melaleucae (Hemiptera: Psyllidae), potential biological control agent for Melaleuca quinquenervia (Myrtaceae). Environmental Entomology 26, 366-372.

Pysek, P., Richardson, D.M., 2007. Traits associated with invasiveness in alien plants: where do we stand. In: Nentwig, W. (Ed.), Biological Invasions. Springer-Verlag, Berlin \& Heidelberg, pp. 97-125.

Raulings, E.J., Morris, K., Roache, M.C., Boon, P.I., 2010. The importance of water regimes operating at small spatial scales for the diversity and structure of wetland vegetation. Freshwater Biology 55, 701-715.

Rayachhetry, M.B., Van, T.K., Center, T.D., 1998. Regeneration potential of the canopy-held seeds of Melaleuca quinquenervia in south Florida. International Journal of Plant Science 159, 648-654.

Reichard, S.H., Hamilton, C.W., 1997. Predicting invasions of woody plants introduced into North America. Conservation Biology 11, 193-203.

Rejmánek, M., Richardson, D.M., 1996. What attributes make some plant species more invasive? Ecology 77, 1655-1659.

Rouget, M., Richardson, D.M., 2003. Inferring process from pattern in plant invasions: a semimechanistic model incorporating propagule pressure and environmental factors. The American Naturalist 162, 713-724.

Russell-Smith, J., Setterfield, S.A., 2006. Monsoon rain forest seedling dynamics, northern Australia: contrasts with regeneration in eucalypt-dominated savannas. Journal of Biogeography 33, 1597-1614.

Salter, J., Morris, K., Read, J., Boon, P.I., 2010. Understanding the potential effects of water regime and salinity on recruitment of Melaleuca ericifolia Sm. Aquatic Botany 92, 200-206.

SAS Institute, 1999. The SAS/STAT User's Guide. SAS Version 8. SAS Institute, Cary, NC.

Serbesoff-King, K., 2003. Melaleuca in Florida: a literature review on the taxonomy, distribution, biology, ecology, economic importance, and control measures. Journal of Aquatic Plant Management 41, 98-112.

SERC, 2007. Naples, Florida (086078) Period of Record Monthly Climate Summary. Available via DIALOG. <http://www.sercc.com/cgi-in/sercc/cliMAIN.pl?fl6078> (cited 17.11.07)

Tipping, P.W., Center, T.D., 2002. Evaluating acephate for insecticide exclusion of Oxyops vitiosa (Coleoptera: Curculionidae) from Melaleuca quinquenervia. Florida Entomologist 85, 458-463.

Tipping, P.W., Martin, M.R., Pratt, P.D., Center, T.D., Rayamajhi, M.R., 2008. Suppression of growth and reproduction of an exotic invasive tree by two introduced insects. Biological Control 44, 235-241.

Tipping, P.W., Martin, M.R., Nimmo, K.R., Pierce, R.M., Smart, M.D., White, E. Madeira, P.T., Center, T.D., 2009. Invasion of a West Everglades wetland Melaleuca quinquenervia countered by classical biological control. Biological Control 48, 73-78. 
Turnbull, L.A., Crawley, M.J., Rees, M., 2000. Are plant populations seed-limited? A review of seed sowing experiments. Oikos 88, 225-238.

USDA, 1998. Soil Survey of Collier County Area, Florida. United States Department of Agriculture, Natural Resource Conservation Service.

Van, T.K., Rayachhetry, M.B., Center, T.D., Pratt, P.D., 2002. Litter dynamics and phenology of Melaleuca quinquenervia in south Florida. Journal of Aquatic Plant Management 40, 22-27. van der Valk, A.G., 2005. Water-level fluctuations in North American prairie wetland. Hydrobiologia 539, 171-188.

Watt, S.L.C., García-Berthou, E., Vilar, L., 2007. The influence of water level and salinity on plant assemblages of a seasonally flooded Mediterranean wetland. Plant Ecology 189, 71-85.

Woodall, S.L., 1982. Seed dispersal in Melaleuca quinquenervia. Florida Scientist 45, $81-93$. 